\title{
Huellas nómadas: Un poema en el bolsillo de Héctor Abad Faciolince
}

\author{
Elide Pittarello \\ Universidad Ca' Foscari, Venecia
}

\begin{abstract}
Resumen:
En 2006 el escritor colombiano Héctor Abad Faciolince (1958) consigue un asombroso éxito internacional con El olvido que seremos, un delicado homenaje literario al padre asesinado en 1987 por sicarios paramilitares. Cruzando culturas y fronteras, el libro enlaza una tragedia familiar con la violencia política del país, pero dejando abierto el final mientras la justicia transicional no dé acceso a la verdad. En 2015 Daniela Abad, hija del escritor, y Miguel Salazar ruedan el documental Carta a una sombra, en parte basado en este libro. Ahora la post-memoria filmica de un crimen de lesa humanidad alcanza un público innumerable y globalizado, mientras el escritor sigue llevando a cabo su forma de reparación personal. Viajando entre dos continentes, averigua la autenticidad del poema de J. L. Borges que el padre llevaba consigo cuando murió. En 2009 publica el resultado - "Un poema en el bolsillo"- primero en la revista Letras Libres, luego en Traiciones de la memoria, un libro ilustrado con muchos documentos. Las combinaciones verbo-visuales de esta memoria en movimiento aportan nuevos cronotopos, analizados con el planteamiento de los Visual Studies. En particular, destaca una imagen superviviente del trauma como prueba de que cada metamorfosis aplaza el trabajo del duelo.
\end{abstract}

Palabras clave: Memoria histórica, globalización, transmedia, imagen verbo-visual, Visual Studies

\begin{abstract}
:
In 2006 the Colombian writer Héctor Abad Faciolince (1958) achieves an astonishing international success with El olvido que seremos, a delicate literary tribute to his father killed in 1987 by paramilitary hitmen. Crossing cultures and borders, the book links a family tragedy to the country's political violence, but leaving an open ending while the transitional justice does not give access to the truth. In 2015 Daniela Abad, the daughter of the writer, and Miguel Salazar shoot the documentary Carta a una sombra, partially based on this book. Now the filmic postmemory of a crime against humanity reaches an uncountable and globalized audience, while the writer continues to carry out his personal way of reparation. Travelling between two continents, he finds out the authenticity of the poem by J. L. Borges that his father took with him when he died. In 2009 Héctor Abad Faciolince publishes the result — "Un poema en el bolsillo" - first in the magazine Letras Libres, then in Traiciones de la memoria, a book illustrated with a lot of documents. The verbal-visual combinations of this memory in motion carry new chronotopes, analysed with the Visual Studies approach. In particular, a surviving image of trauma stands out as a proof that every metamorphosis delays the grief process.
\end{abstract}

Keywords: Historical Memory, globalization, transmedia, verbal-visual image, Visual Studies 


\section{Colombia, un punto de partida}

El 24 de agosto de 2016, siendo presidente Juan Manuel Santos, una delegación del gobierno de Colombia y una delegación de la guerrilla de las FARC firman en La Habana un acuerdo de paz, fruto de largas negociaciones en un contexto institucional complicado. Junto con la soberanía nacional, en Colombia interactúan tanto los imperativos jurídicos internacionales, que responsabilizan al Estado acerca de la defensa de los derechos humanos y el castigo de las conductas criminales, como el activismo legal transnacional de las ONG (López Pacheco 255-286), más varios organismos de control intergubernamentales etc. Entre las medidas tomadas para solucionar los conflictos armados internos, cabe recordar al menos la Constitución Política de Colombia, de 1991, conocida como la Constitución para la Paz, donde la paz — en tanto que derecho individual y colectivo para la solución negociada del conflicto- tendría que ser "un presupuesto lógico de la verdad, la justicia y la reparación" (Moreno Millán 312). En 2005, siendo presidente Álvaro Uribe, con la Ley de Justicia y Paz, se promueve la desmovilización y reinserción en la vida civil de los grupos armados. Las condenas de los victimarios son tan blandas que rozan la impunidad. A las víctimas, en cambio, no se les garantiza ni una efectiva restitución, ni el rastreo de la verdad, aparte de la que podía averiguarse en el ámbito de las instancias judiciales (Valencia Agudelo y Mejía Walker 59-77). Bajo la presidencia de Juan Manuel Santos, en 2011, se promulga la Ley de Victimas y Restitución de Tierras donde cobra importancia la figura de la víctima, una condición extendida a los familiares en primer grado de consanguineidad y a los cónyuges. La ley apunta a finalizar los conflictos armados según la lógica de la justicia transicional, la que tiende a conseguir "un equilibrio razonable entre las exigencias contrapuestas de la justicia y de la paz, entre el deber de castigar el crimen impune y honrar a sus víctimas, y el deber de reconciliar a los antiguos adversarios políticos" (Valencia Villa 76). En este sentido, el acuerdo de paz firmado en La Habana representa un avance enorme y como tal lo celebra públicamente el escritor colombiano Héctor Abad Faciolince: el 27 de agosto en el diario nacional El Espectador (Abad Faciolince "Un poeta, un filósofo, un tendero y un tropero") y el 3 de septiembre en Babelia, el suplemento cultural del diario español El País (Abad Faciolince, "Ya no me siento víctima"). El padre del escritor, el médico Héctor Abad Gómez, había sido asesinado por dos sicarios de un grupo paramilitar en una calle de Medellín, el 25 agosto de 1987: con este antecedente ambos artículos revelan el férreo compromiso del hijo con una memoria que por un lado se ciñe al contexto colombiano y por otro sintoniza con un ámbito transnacional y transcultural.

La memoria del trauma es resistente. Se activa no solo porque la experiencia resultó en su momento incomprensible, presiona por ser relatada una y otra vez con modalidades diferentes (Caruth 11-12). Héctor Abad Gómez, catedrático de la universidad de Antioquia al que habían jubilado de punto en blanco a los 61 años por su activismo socio-político, presidía el Comité para la defensa de los derechos humanos cuando lo mataron. Poco antes su hijo Héctor había vuelto a casa tras haberse licenciado en Lenguas y Literaturas Modernas en la universidad italiana de Turín. Un cuarto de siglo después, conmemorando el aniversario de la muerte del padre, el escritor recuerda cómo había abandonado su país para ponerse a salvo: 
Recuerdo un vuelo tristísimo, en un avión completamente vacío, que atraviesa el Atlántico el día de Navidad. Lo tomé en Panamá, y aterricé en Madrid en la madrugada del 25 de diciembre. Pocas semanas después, en enero de 1988 estaba en Turín, la ciudad donde había hecho la universidad. De alguna manera yo sentía que Europa era la casa de todos: la casa de mi idioma, de buena parte de mi cultura, la casa de una religión en la que yo ya no creía, pero que había sido la de mis mayores. Era tan profundo mi resentimiento con Colombia y tan hondo mi agradecimiento con Europa, que en esos años yo quería volverme italiano. (Abad Faciolince, "A las dos orillas del mundo")

Obviamente Héctor Abad Faciolince no llevará a la práctica esa intención, pero echa raíces también familiares. En Italia trabaja durante cinco años como lector de lengua española en la universidad de Verona. Vuelve a Colombia en 1992 y a partir de entonces se dedica sobre todo al periodismo y a la literatura. Como resulta de su página oficial en la web, aparte de una intensa actividad de columnista siempre alerta sobre los peligros que atraviesa la sociedad de su país y del resto mundo, Héctor Abad Faciolince tenía publicados varios libros cuando dio a la imprenta El olvido que seremos (2006). Es el relato de la tragedia familiar que enlaza con las vicisitudes socio-políticas de Colombia. Habían pasado casi veinte años entre el asesinato del padre y su rememoración en forma de libro, una distancia temporal y un medio - la escritura- que implica un procesamiento lleno de incógnitas emocionales y pragmáticas. La reivindicación retrospectiva de la verdad tiene que lidiar por un lado con la fidelidad al trauma y la resistencia a elaborar el duelo por miedo a traicionar a la persona querida y muerta (LaCapra 161). Por otro tiene que romper el silencio institucional que rodea el crimen y sume a los supervivientes en una angustia sin fin. Publicado por la editorial Alfaguara, El olvido que seremos tuvo una proyección internacional inmediata. Limitadamente a la recepción en lengua española, lo elogiaron escritores como Javier Cercas, Rosa Montero, Manuel Rivas, Fernando Savater, Mario Vargas Llosa, Juan Villoro entre otros (Escobar Mesa 167-168).

La admiración por la calidad literaria del libro se mezclaba con la empatía, un sentimiento redescubierto recientemente como dispositivo multidisciplinar que atiende también a funciones cognitivas, éticas, estéticas, históricas, políticas etc. Diferente de la simpatía, la piedad o la compasión, la empatía implica comprender la actitud del otro a través de la imaginación, respetar su vivencia sin suplantarla, compartir la visión ajena del mundo manteniendo la diferencia subjetiva, social y cultural de uno mismo (Assman y Detmers 3-7). El desasosiego empático que, entre sus efectos, tendría que cohibir el tratamiento supuestamente objetivo del trauma ajeno (LaCapra 120), tal vez haya contribuido a formar en este caso una vaga reparación por medio de un público lector que tiene una escucha diferida y virtualmente sin fronteras. Es cierto, sin embargo, que cuando salió El olvido que seremos el autor y su familia seguían sin conocer la identidad de los sicarios, un incumplimiento grave por lo que se refiere a la justicia transicional. Si es el Estado el que tiene que garantizarles a las víctimas "el acceso igual y efectivo a la justicia; la reparación adecuada, efectiva y rápida del daño sufrido, y el acceso a información pertinente sobre las violaciones y los mecanismos de reparación" (Valencia Villa 81), El olvido que seremos testimonia iniquidades manifiestas. En 2014, después de que la Fiscalía había abandonado la investigación jamás afrontada con eficacia, el asesinato de Héctor Abad Gómez fue declarado crimen de lesa humanidad. Según el Estatuto de Roma de la Corte Penal Internacional de 1998, este delito no prescribe. Por otra parte, el tiempo no pasa en vano para los familiares de las víctimas. El propio 
Héctor Abad Faciolince, declarando que en el referéndum convocado para el 2 de octubre de 2016 votaría a favor del acuerdo alcanzado en La Habana, parecía pactar con la reivindicación insoslayable de la víctima, el derecho a la verdad. Lejos de ser una capitulación o una renuncia, esta actitud política es la consecuencia de un largo aprendizaje del dolor:

las historias familiares, que son como una novela real, me han obligado a sentir y me han enseñado a pensar mucho sobre el sufrimiento, sobre la justicia y la impotencia, sobre la humillación y la rabia, sobre la venganza y el perdón. Escribir la injusticia que se cometió con mi padre, el asesinato de un hombre bueno, me curó de la necesidad de aspirar a ver en la realidad la representación de la justicia (una cárcel para los asesinos). De alguna manera yo siento que pude hacer justicia contando la historia tal como fue. (Abad Faciolince, "Ya no me siento víctima")

Sin embargo, basta con que gane por sorpresa el frente del NO para que el escritor publique en El País un artículo impetuoso y dolido, donde se lee entre líneas que en realidad aún se sentía víctima. Además, no dejaba de ser paradójico el hecho de que el presidente Juan Manuel Santos estuviera a punto de recibir en Oslo el Nobel de la Paz 2016 en virtud de aquel acuerdo que acababa de ser rechazado. En Colombia, poco más de la mitad de los votantes del referéndum se oponía a la política que la comisión noruega había valorado con aquel premio. Por su parte, Héctor Abad Faciolince contestaba la opinión de que el resultado frustrante se debiera a la ignorancia que supuestamente afecta al pueblo colombiano. En su opinión, semejante demérito sería común a la política de muchos países, como muestran el Brexit, la pérdida de consenso de Angela Merkel al acoger a los refugiados, el fracaso de la primavera árabe y —acertando el resultado de las inminentes elecciones presidenciales norteamericanas- la victoria de Donald Trump. La conclusión del autor es que el populismo es ya una plaga mundial y repercute también en el destino de Colombia:

El 2 de octubre se acabó el periodo de Santos, el presidente que hizo el esfuerzo más serio por la paz y alcanzó a firmarla, para verla caer ocho días después. Gobernará por ley y por inercia hasta el 7 de agosto de 2018. Y el proceso de paz seguirá en un limbo de incertidumbre jurídica y real. Pero eso no importa, Colombia es el país en el que todo es provisional, todo es por el momento, mientras tanto. Un país hiperactivo y sobreexcitado, experto en drogas estimulantes: cafeína, cocaína, nicotina, alcohol. No es que los encuestadores fracasaran al pronosticar el triunfo del si; lo que pasa es que la gente contestó mentiras, les daba vergüenza votar por el no, pero votaron. Así como les da vergüenza decir que votarán por Trump, pero votarán. Los que votamos por el sí soñábamos con "una paz estable y duradera". La mayoría, el no, votó por una incertidumbre estable y duradera. $\mathrm{Al}$ fin y al cabo ese es el verdadero trending topic de Colombia, ahora y siempre: \#UnaIncertidumbreEstableYDuradera. Como estará el mundo entero cuando amanezca el 9 de noviembre del 2016 y haya ganado Trump. Yo ya sé lo que se siente: miedo, tristeza y desesperación. (Abad Faciolince, "Explicar el fracaso")

En contra de los que no confiaron en el acuerdo de paz, las FARC entregaron las armas en junio de 2017 y hoy son un partido político. Han guardado el mismo acrónimo la identidad originaria-, pero ahora corresponde a una denominación diferente: Fuerza Revolucionaria Activa del Común en lugar de Fuerzas Armadas Revolucionarias de Colombia. Tras participar en las elecciones políticas de 2018, por primera vez sus 
representantes ocupan 10 escaños en el Congreso, no obstante, el número insuficiente de votos conseguidos. También esto se debe a aquel acuerdo de paz. Mientras tanto, el presidente Iván Duque, elegido con el respaldo del expresidente Álvaro Uribe, va cambiando la narrativa oficial. El estado de la cuestión no es el mismo según y cómo mencionen o callen ciertos lexemas — "conflicto armado", "post-acuerdo" "paz", "guerra", "justicia" etc.— quienes toman el relevo en el poder. Una vez más, al poner en tela juicio estrategias y finalidades de la justicia transicional cada vez que intervienen agentes que se oponen a sus predecesores, las víctimas corren el riesgo de quedarse estancadas en un tiempo detenido aun cuando hayan logrado decir lo que tenían que decir y ser escuchadas (Hartog 16). Mientras el relato del posconflicto quede sometido a revisiones una y otra vez, sigue en suspenso también el valor documental de todo lo que Héctor Abad Faciolince ha publicado y publique sobre la situación de Colombia, a partir de la circunstancia personal. Si la sociedad "no puede prescindir de las inscripciones y de las grabaciones, de los archivos y de los documentos, y sobre todo de aquella especie de "técnica de las técnicas" que es la escritura" (Ferraris 16-17), queda por establecer en qué ámbitos esta memoria es relevante y eficaz. ¿Dónde y cómo se decide si un documento es digno de acaparar la atención o caer en la indiferencia?

\section{Europa, el otro horizonte}

Un texto estremecedor como El olvido que seremos es un documento difícil de catalogar hasta por parte del autor. En una entrevista de 2017 Héctor Abad Faciolince dijo que es "una novela sin ficción” (Marín Yarza). En otras palabras, un relato que no deja de tener un vínculo mimético con lo real, por artístico que sea el uso del lenguaje y de la estrategia narrativa. Hace falta restringir lo literario al conjunto de características formales del texto, pero sin contar con su autonomía estética, la que teorizaron en su momento los formalistas rusos (Jakobson et al.). Lo que está en juego no es la invención de la verosimilitud, sino la reivindicación de la verdad. Por eso en El olvido que seremos la operación de "tramar" o darle una estructura narrativa a acontecimientos reales "es llevada a cabo a partir de técnicas discursivas que, en su naturaleza, son más tropológicas que lógicas" (White 155). No cabe duda de que "la interacción o relación de interrogación mutua entre la historiografía y el arte (incluida la ficción) es mucho más compleja que lo que sugiere una relación de identidad o una oposición binaria entre ambos" (LaCapra 40). Con respecto a uno u otro canon, El olvido que seremos es un libro fronterizo por la cualidad de la escritura y el alcance de la recepción. Ante una globalización acelerada donde los límites perduran para ser rebasados, Héctor Abad Faciolince proyecta El olvido que seremos hacia un más allá espacial y temporal formado por sociedades y culturas impredecibles. Mientras en Colombia la ruta de la justicia transicional siga siendo accidentada, su memoria particular queda parcialmente inconexa con respecto al lugar del trauma. Se entiende entonces por qué el libro termina con una actualización del desengaño barroco. Universalizando la herida que permanece abierta, el narrador enfoca la práctica de la memoria desde la perspectiva de la finitud humana. Fuera del marco causal y teleológico de la historia, y en particular de la historia socio-política de su país, el narrador pluraliza el "yo" del discurso autobiográfico en 
un "nosotros" inclusivo. Participamos del mismo destino desde el íncipit del breve capítulo final:

Todos estamos condenados al polvo y al olvido, y las personas a quienes yo he evocado en este libro o ya están muertas o están a punto de morir o como mucho morirán quiero decir, moriremos - al cabo de unos años que no pueden contarse en siglos sino en decenios. "Ayer se fue, mañana no ha llegado, / hoy se está yendo sin parar un punto, / soy un fue, y un será, y un es cansado [...]", decía Quevedo al referirse a la fugacidad de nuestra existencia, encaminada siempre ineluctablemente hacia ese momento en que dejaremos de ser. Sobrevivimos por unos frágiles años, todavía, después de muertos, en la memoria de otros, pero también esa memoria personal, con cada instante que pasa, está siempre más cerca de desaparecer. Los libros son un simulacro de recuerdo, una prótesis para recordar, un intento desesperado por hacer un poco más perdurable lo que es irremediablemente finito. Todas estas personas con las que está tejida la trama más entrañable de mi memoria, todas esas presencias que fueron mi infancia y mi juventud, o ya desaparecieron, y son sólo fantasmas, o vamos camino de desaparecer, y somos proyectos de espectros que todavía se mueven por el mundo. (Abad Faciolince, El olvido 317)

A través del "nosotros" que "anexa al 'yo' una globalidad indistinta de otras personas" (Benveniste 171), Héctor Abad Faciolince colectiviza lo que ha aprendido del asesinato del padre, quien llevaba en un bolsillo un poema atribuido a Borges. Es este el origen del verso que coincide con el título del libro, un fragmento que se autonomiza con respecto al entero del que procede y cobra una trascendencia propia (Calabrese 100104). Fijándose en aquel fragmento, el escritor eleva la necesidad de recordar que atañe a su familia y a su país a norma universal del viviente: "como el tiempo del recuerdo vivido es tan corto, si juzgamos sabiamente, 'ya somos el olvido que seremos', como decía Borges" (Abad Faciolince, El olvido 317-318). Sin embargo, el desengaño inflama el deseo de memoria en vez de apagarlo. Es este el final abierto del libro. Dado que la memoria no suele superar la duración de la vida humana incluso cuando es colectiva (Halbwachs 88), el autor quiere transmitir idealmente su experiencia urbi et orbi. Cambia la enunciación, pasa al pronombre de segunda persona del plural y apostrofa a los desconocidos lectores para que se involucren en una tarea análoga a través de la empatía. Tal vez sea esta la comunidad invisible e indefinida que cargue con el legado del testigo secundario (secondary witness) para alivio del autor:

Y si mis recuerdos entran en armonía con algunos de ustedes, y si lo que yo he sentido ( $y$ dejaré de sentir) es comprensible e identificable con algo que ustedes también sienten o han sentido, entonces este olvido que seremos puede postergarse por un instante más, en el fugaz reverberar de sus neuronas, gracias a los ojos, pocos o muchos, que alguna vez se detengan en estas letras. (Abad Faciolince, El olvido 319)

El testigo del trauma no está nunca solo si puede contar con testigos secundarios que interpretan su relato, difundiendo nuevos puntos de vista. El hecho mismo de transmitirles el testimonio construye un espacio dialógico (Violi 54), aparte de funcionar también como posible antídoto de la victimización (LaCapra 62). En este sentido, la escritura de Héctor Abad Faciolince tiende a una forma de reparación sin fronteras que complica la construcción social y cultural del trauma, incluso si aspira uno a la memoria multidireccional, la que se propone integrar en un marco histórico-social colectivo experiencias individuales diferentes (Rothberg 5-21). Entre la publicación de 
El olvido que seremos y del artículo "Ya no me siento víctima" pasan diez años. En este lapso de tiempo el autor vuelve sobre el trauma ya que, como es sabido, no deja uno de librarse de su impacto. Lo aprieta la necesidad de ofrecer testimonios que resitúen una y otra vez el acontecimiento inaceptable (Caruth 4-11). Junto con aquella escritura, Héctor Abad Faciolince ha ido elaborando formas de memoria transmedial que desempeñan un papel transcultural por su capacidad de propagar y metamorfosear lo individual y lo colectivo en el espacio y en el tiempo, conectando diferentes ámbitos sociales, lingüísticos y políticos (Erll 11). Entonces aquel crimen sucedido en Medellín el 25 de agosto de 1987 no cae en el olvido. Su memoria se difunde y perdura entre un público cada vez más vasto y heterogéneo, como sucede con el largometraje Carta a una sombra que dirigen Daniela Abad, hija del escritor, y Miguel Salazar.

Se estrena en 2015, en el Festival Internacional de Cine de Cartagena de Indias, recibiendo allí los primeros galardones de una larga serie. Sin ser una adaptación, la película se inspira en El olvido que seremos, integrada con otros documentos sacados del archivo familiar (cartas, fotos, casetes etc.) y de archivos públicos (periódicos, vídeos, grabaciones radiofónicas etc.). Sucesivamente Carta a una sombra se proyecta en otras ciudades de Colombia, en el Festival de Cine de Lima y, a partir de 2016, también en instituciones culturales y festivales europeos (Holanda, Francia, Italia, España etc.). Se ensancha así la comunidad de los destinatarios de aquella memoria, se refuerza e internacionaliza la solidaridad pública, elemento fundamental en el proceso de reparación. El sufrimiento de una familia alcanza la esfera política por el mero hecho de desarmar la conspiración del silencio institucional. La lucha tiene que encarar varios tipos de olvidos, desde la negación y la negligencia del Estado hasta el desinterés y el desconocimiento de la sociedad civil (Fassin y Rechtman 168). Con todo, tiene una relevancia especial haber proyectado el documental el 3 de octubre de 2017, en la Cineteca Matadero de Madrid, con motivo de la reedición en Alfaguara de El olvido que seremos.

Por los límites de este trabajo, solo cabe comentar brevemente un número exiguo de secuencias de Carta a una sombra. De entrada, hago hincapié en ese pase madrileño a fin de evidenciar el múltiple papel de Héctor Abad Faciolince, que estaba presente. Él es el autor del libro que inspira el documental; es coautor del guion; es el intérprete que lee en voz alta fragmentos de su propio relato; es el actor de otras escenas rememorativas, encuadrado solo o con su familia o con Carlos Gaviria, íntimo amigo del padre; finalmente es el espectador de sí mismo dentro del largometraje que ha rodado su hija — una niña, cuando murió el abuelo— en colaboración con Miguel Salazar. En esta dirección compartida, Daniela Abad, la nieta de Héctor Abad Gómez que creció en Italia y vive ahora en Medellín, le toma el relevo a su padre. Es ella la que vuelve a narrar el trauma, pero con el medium fílmico y el enfoque de la postmemoria familiar (Hirsch 113-115). Debido a su compleja combinación de códigos cinematográficos, el documental alcanza no solamente a un público más globalizado sino que lo informa de otra manera, involucra también sus sentidos, engarza las emociones en las competencias. 


\section{Tiempos rotos}

Volvamos a Héctor Abad Faciolince. Cuando participa en la realización de Carta a una sombra, para su sorpresa descubre o recupera partes de aquella experiencia que se habían difuminado con el paso de tantos años. Instalada en la duración, la capacidad de ahondar en la memoria es "una figura del cuidado" a través del cual "nos mantenemos cerca del pasado, seguimos estando preocupados por él” (Ricœur 656). Aquí una prueba especialmente llamativa de esta forma de cuidado es lo que sucede en el documental a partir del momento en que el escritor está conduciendo un coche, concluida ya la visita a la aldea originaria de los Abad, su estirpe patrilineal. La cámara lo encuadra de perfil, tiene la expresión serena. Mientras mira la carretera que atraviesa un armonioso paisaje natural, dice de pronto con una voz apacible: "Una vieja teoría que yo tengo es que los poemas son una forma de rezo o, mejor dicho, que el rezo es una forma de poesía y que por eso a la gente le gusta tanto rezar y realmente encuentran en el rezo mucha calma" (Abad y Salazar). Este silogismo introduce un flashback, la memoria del asesinato del padre, un anacronismo fílmico intrusivo que aún no se puede contar como pasado (Luckhurst 180). En El olvido que seremos el escritor lo había relatado en presente de indicativo, el tiempo verbal que remite a la enunciación subjetiva del locutor (Benveniste 182-184). Es este un recurso de la escritura para expresar la coincidencia ilusoria entre el acontecimiento y el discurso que lo refiere:

Corremos y ahí está, boca arriba, en un charco de sangre, debajo de una sábana que se mancha cada vez más de un rojo oscuro, espeso. Sé que le cojo la mano y que le doy un beso en la mejilla y que esa mejilla todavía está caliente. Sé que grito y que insulto, y que mi mamá se tira a sus pies y lo abraza. No sé cuánto tiempo después veo llegar Carlos Gaviria, con la cara transfigurada de dolor, y yo grito que se vaya, que se esconda, que tiene que irse porque no queremos más muertos. Entre mi hermana, mi cuñado y yo rodeamos el cadáver. Mi mamá le quita la argolla de matrimonio y yo saco los papeles de los bolsillos. Más tarde veré lo que son: uno es la lista de los amenazados de muerte, una fotocopia, y el otro, el epitafio de Borges copiado de su puño y letra, salpicado de sangre: "Ya somos el olvido que seremos". (Abad Faciolince 286)

En el largometraje, al contar oralmente la misma experiencia, el escritor omite algunos detalles y añade otros, sin variar demasiado el núcleo referencial de la versión impresa en El olvido que seremos, exceptuando el uso del tiempo verbal, el pretérito indefinido. Al desempeñar en persona el papel del testigo, en 2015 el autor parece haber entregado esa experiencia al discurso histórico. Sin embargo, tras mencionar el hallazgo del poema, se pone a recitar los primeros versos, es decir él mismo empieza a rezar. En un contexto nada hierático, mientras sigue conduciendo el coche con naturalidad, el autor vocaliza un decir que la escritura - lo dicho visible en la página- no puede abarcar. El vuelco semiótico es trascendente. La voz que interpreta el poema afecta al cuerpo, testimonia la unicidad del viviente que la emite. Al salir de una garganta, con su modulación sonora la voz niega la abstracción del lenguaje, soslaya la idealización metafísica del sujeto (Cavarero 38-39). En esta secuencia de Carta a una sombra la voz de Héctor Abad Faciolince irrumpe en la escucha del espectador con el poema/rezo abriendo paso, sin solución de continuidad, a la voz en off de su propio padre. Nada la anuncia, el espectador tiene que reconocer la sonora huella fantasmal por el timbre diverso, vigoroso, que ya había escuchado previamente en fragmentos de discursos 
filmados. Durante unos instantes la voz del padre muerto se superpone a la voz del hijo vivo. Gracias al medium fílmico se realiza entre ambos el reencuentro imposible. Luego el hijo sigue conduciendo en silencio. La huella vocal del padre termina de recitar/rezar el poema asociado a su muerte.

A continuación, tras el último verso recitado hay un cambio de plano metonímico. Se ve ahora al escritor en el cementerio mientras limpia la tumba del padre y pone unas flores. La cámara encuadra la losa funeraria que lleva grabado el poema. Es esta la imagen ineluctable, la que asocia la visión a la pérdida (Didi-Huberman, Lo que vemos 17). También es la imagen que confirma la fidelidad al trauma (LaCapra 46). El papel arrugado donde el padre había transcrito el poema se había perdido. Tal vez pareciera sacrílego guardar aquel documento/reliquia manchado de sangre. Pero lo reemplaza, sólido y labrado, el mármol de la tumba. Este documento/monumento está a la vista en el cementerio, honra la memoria de la víctima con los catorce versos cincelados. La losa de piedra en lugar de la hoja de papel. Los restos mortales custodiados con miramiento en lugar del cadáver matado a tiros, tendido en una acera de Medellín. El texto del poema queda permanentemente vinculado al cuerpo de la víctima mortal (el padre) y también al cuerpo de la víctima viva (el hijo) que sigue velando por aquella memoria. Gracias a la transmedialidad de Cartas a una sombra, en la secuencia del cementerio Héctor Abad Faciolince personifica la imagen superviviente que ha expresado otras veces por escrito. Han pasado casi cuatro décadas. El autor tiene la barba y el pelo canosos, su actitud es sosegada mientras sigue profesándole devoción al pasado que no termina de pasar, que no evoluciona. En torno al poema ha cuajado una imagen indestructible y metamórfica del trauma, afín a la Pathosformel de Aby Warburg, la "fórmula de pathos" donde el momento rememorativo constituye "algo esencialmente anacrónico: es un presente en el que se agitan o actúan las supervivencias. Anacrónico en cuanto que intenso e intrusivo, anacrónico en cuanto que complejo y sedimentado" (Didi Huberman, La imagen 282). La elaboración del trauma no sigue la cronología, marca una brecha que se transforma pero no se sutura.

\section{Eclosión de huellas}

Las secuencias del largometraje que se acaban de comentar constituyen, de momento, la etapa más reciente de las vicisitudes que el poema ha sorteado a raíz de la publicación de El olvido que seremos en 2006. Entonces Héctor Abad Faciolince había atribuido el texto a Borges, pero la reacción polémica de algunos lectores lo llevó a acometer una empresa filológica a todas luces aventurera. Debido a la recepción de ese detalle, desde Berlín donde estaba viviendo, el escritor asume el desafío de investigar y contar la procedencia del poema, pero inscribiéndola en otro género de discurso. Es el del reportaje: se basa en el testimonio personal, pero aborda su objeto con el estilo fáctico que el médium periodístico requiere. En agosto de 2009 el autor publica el resultado en la revista Letras Libres, en sendas ediciones de México y España. El texto, titulado "Un poema en un bolsillo", inaugura el dosier Borges inédito. El autor, admitiendo que su memoria es quebradiza, escribe muy al comienzo: 
Como yo no recuerdo bien lo que pasó al caer la tarde del 25 de agosto de 1987, como el recuerdo es confuso y está salpicado de gritos y lágrimas, voy a copiar un apunte de mi diario, escrito cuando aquello estaba todavía fresco en la memoria. Es un apunte muy breve:

Lo encontramos en un charco de sangre. Lo besé y aún estaba caliente. Pero quieto, quieto. La rabia casi no me dejaba salir las lágrimas. La tristeza no me permitía sentir toda la rabia. Mi mamá le quitó la argolla de matrimonio. Yo busqué en los bolsillos y encontré un poema.

Hasta ahí el diario, en la entrada del 4 de octubre del año 87. Después hay algunas citas dispersas de versos del poema, pero en mi cuaderno no transcribo el poema completo. El poema completo lo publiqué después, el 29 de noviembre de 1987, en el Magarín Dominical de El Espectador. Ahí digo, por primera vez, que el poema es de Borges.

(Abad Faciolince, "Un poema en el bolsillo" 10)

Con respecto a la versión publicada en El olvido que seremos (2006) y a la versión oral de Carta a una sombra (2015), esta variante intermedia (2009) distribuye los elementos relativos a la representación del trauma de otra manera, excepto un par de ellos, siempre acoplados: el gesto de la madre que le quita la alianza al marido y el gesto del hijo que saca el poema de un bolsillo del padre. Como si formaran una Sagrada Familia que acaba de ser destrozada por la violencia homicida, la madre y el hijo guardan inmediatamente para sí el objeto que materializa el respectivo vínculo amoroso con el cadáver del patriarca, cuya sangre aún no ha dejado de manar. Es esta la imagen literaria más resistente, la que escribe "un proceso de mirada que las palabras asumen en el curso de su composición" (Didi-Huberman, La imagen 191). Haber tomado la decisión de descubrir cómo el poema le llegó al padre y si es efectivamente de Borges conlleva una peripecia de la memoria que atraviesa medio mundo, incluyendo escorzos de vidas ajenas, ubicadas en Europa, América del Sur y América del Norte.

Las huellas son improntas reconocidas que cuentan historias complejas, su autenticidad se construye, son el resultado de una atribución cultural llevada a cabo a través de negociaciones que a veces fallan. Las huellas sirven a veces para tergiversar la verdad o mentir directamente (Violi 90-100). De hecho, el primer interlocutor de Héctor Abad Faciolince es el poeta colombiano Harold Alvarado Tenorio, que con sus contradicciones premeditadas obstaculiza el proyecto hasta el punto de atribuirse la autoría del poema. Luego desfilan muchas personas con mejores intenciones como la epidemióloga Bea Pina desde Finlandia, la novelista y guionista de cine argentina Sara Rosenberg desde Madrid, el poeta Gabriel Jiménez Emán desde Venezuela y, desde Estados Unidos, el profesor Daniel Balderston de la University of Iowa y el profesor Julio Ortega de la Brown University. En la larga lista de personas consultadas, no falta María Kodama, la viuda de Borges que confirma, a través de un editor, que el poema es apócrifo.

Héctor Abad Faciolince se desanima: "Yo no veía ningún camino para esclarecer el enigma, pero me puse terco: quería luchar contra el olvido y contra la negación de ese poema" (Abad Faciolince, "Un poema en el bolsillo" 13). Metonimia del trauma, el poema es lo esencial del recuerdo. A su pesar, el escritor está punto de abandonar la búsqueda cuando lo socorre un hecho inesperado. En Medellín, en la pequeña librería de viejo que tiene con un grupo de amigos, entra un día una señora, Tita Botero. Lleva una página recortada de la revista Semana, fechada 26 de mayo de 1987. Había sido guardada durante veinte años en un libro de Borges que pertenecía a su marido. Esa 
página salida azarosamente a la luz revelaba que un grupo de estudiantes de Mendoza (Argentina) había publicado trescientos ejemplares de un librito con cinco poemas inéditos de Borges. La revista reproducía dos poemas, uno de ellos es el que llevaba en el bolsillo Héctor Abad Gómez, quien estaba suscrito a la revista. Posiblemente viera allí el poema. Con esta nueva pista el escritor contacta otras personas mientras viajan también los documentos, entre ellos una grabación que Luza Ruiz, una estudiante de periodismo contratada ex profeso, le envía desde Medellín. La grabación procede de un programa de radio de la Universidad de Antioquia:

Hacía casi veinte años que yo no oía la voz de mi padre. De un momento a otro, una lluviosa tarde de primavera en Berlín, recibí como del más allá, como de la ultratumba, la voz de mi padre recitando ese soneto que pocas semanas después copiaría a mano y se echaría en el bolsillo. Hay un pedazo de un soneto de Borges sobre su propio padre que debo citar en este momento: "La mojada / tarde me trae la voz, la voz deseada, / de mi padre que vuelve y que no ha muerto." Varias veces aspiró Borges al milagro de volver a escuchar, así fuera por un instante, la voz de su padre. Recuperar esa voz, según él, sería la más alta negación del olvido. (Abad Faciolince, "Un poema en el bolsillo" 13)

Entre todos los versos de Borges, son estos los que respaldan la añoranza del escritor. La voz grabada del padre recitando el soneto, la que sería utilizada en el documental Carta a una sombra, abre un palimpsesto de temporalidades propias y ajenas. Atesorando el hallazgo, el autor persevera en su práctica detectivesca. Viaja a Mendoza, a París, a Buenos Aires. Se entrevista con Jaime Correas, Coco Romairone, Jean-Dominique Rey, el matrimonio Franca Beer y Guillermo Roux, reúne más testimonios y más documentos hasta tener la certeza de que ese poema es de Borges. A partir de la supervivencia ruinosa de un texto copiado a mano en un papel, practicando la abducción Héctor Abad Faciolince consigue ese tipo de conocimiento indiciario que descifra una realidad opaca (Ginzburg 158-193). En Buenos Aires, dando por concluida la investigación, decide contar la historia. La concluye retomando el móvil originario, el trauma:

soy un olvidadizo, un distraído, a ratos un indolente. Sin embargo, puedo decir que gracias a que he tratado de no olvidar esta sombra, mi padre, arrebatado a la vida en la calle Argentina de Medellín, me ha ocurrido algo extraordinario: aquella tarde su pecho iba acorazado solamente por un frágil papel, un poema, que no impidió su muerte. Pero es hermoso que unas letras manchadas por los últimos hilos de su vida hayan rescatado, sin pretenderlo, para el mundo, un olvidado soneto de Borges contra el olvido. (Abad Faciolince, "Un poema en el bolsillo" 18)

Emerge una verbalización inédita alrededor del núcleo resistente y desasosegado del poema, cuya imagen es al mismo tiempo arqueológica y vigente, fósil y experiencial (Didi-Huberman, Falenas 125). El narrador realza primero la fragilidad del soporte, la paradójica armadura de papel que estuvo en contacto con el cuerpo de su padre, un pacifista militante. Luego enfoca las letras, las huellas de tinta que la mano del padre había depositado cuando aún vivía, ulteriores señas de identidad, exclusivas como su voz. Finalmente lleva a cabo una metamorfosis icónica de las manchas de sangre, vistas ahora como delgadas ataduras sacrificiales ("últimos hilos de su vida") que enlazan la finitud somática de la víctima con el más allá de la posteridad artística, un porvenir incalculable. Convergen en el documento del poema la pérdida luctuosa particular y el 
hallazgo poético cosmopolita. Gracias a la obstinada y amorosa investigación del autor, aquellos versos se inscriben en una axiología de la reparación, doblemente beneficiosa: son motivo de consuelo personal e incrementan el patrimonio literario del mundo.

Cuando uno indaga un detalle acaba mirando más a fondo el conjunto del que está sacado y descubre aspectos que antes no había percibido (Calabrese 88). Con eso y todo la memoria del trauma sigue latiendo, por mucho que pacte con los síntomas no deja de inventar alguna "fórmula de pathos", impuesta por la vivencia del presente, siempre en devenir. Quizá por eso Héctor Abad Faciolince, después de publicar en Letras libres el resultado de su indagación, a finales del mismo año (2009) retoma el texto y, con escasas variantes y ampliaciones, lo incluye en el volumen Traiciones de la memoria, junto con otros dos relatos. Tal vez por no confiar suficientemente en la eficacia de las palabras, ahora el autor rompe la fluidez del enunciado con la reproducción de una enorme cantidad de documentos (manuscritos, páginas de periódico, fotos, cartas, libros etc.) que afectan considerablemente a la interpretación. El lector tiene que añadir a su papel habitual el papel del espectador, ahora ve con sus propios ojos de qué habla el relato. Las imágenes reproducidas son pruebas visibles que el lector/espectador tiene que interpretar contando con su propio cuerpo (Belting 156), tiene que encararlas como si tuvieran vida y le exigieran cosas (Mitchell 29). Producto de un riquísimo montaje intermedial, "Un poema en el bolsillo" se inaugura ahora con un nuevo íncipit. Lo impregna un aura doliente. El autor reitera el móvil de su narración:

Yo no hubiera querido que la vida me regalara esta historia. Yo no hubiera querido que la muerte me regalara esta historia. Pero la vida y la muerte me regalaron, no, mejor dicho me impusieron la historia de un poema encontrado en el bolsillo de un hombre asesinado y no pude hacer otra cosa que recibirla. Ahora quiero contarla. Es una historia real, pero tiene tantas simetrías que parece inventada. Si no fuera verdad, podría ser una fábula. Aún siendo verdad es una fábula. (Abad Faciolince, "Un poema en el bolsillo" 17)

Esta versión de "Un poema en el bolsillo" puede definirse una edición ilustrada solo a condición de repristinar la etimología del verbo correspondiente: "ilustrar" en el sentido de esclarecer, dar a conocer, acreditar a través de la vista. Todo menos un añadido decorativo, aun tratándose de una edición preciosa que compagina armoniosamente la estética con la ética. Por lo que hemos aprendido sobre la relación entre la palabra y la imagen a partir de los Visual Studies, puede decirse que aquí las ilustraciones no complementan el relato testimonial, lo fisuran, desbaratan su cronología y su diégesis. Contar la historia del poema también con imágenes presupone muchos desvíos con respecto a la linealidad cronológica. Interviene la práctica del montaje, el cual "escapa a las teleologías, hace visibles las supervivencias, los anacronismos, los encuentros de temporalidades contradictorias que afectan a cada objeto, cada acontecimiento, cada persona, cada gesto" (Didi-Huberman, "Cuando las imágenes" 359). Cada imagen reproducida lleva un pie de foto del autor, un comentario manuscrito, una minúscula imagen adicional. Cada página ilustrada es un montaje a pequeña escala dentro del montaje mayor, pasando de lo más íntimo y local a lo más notorio y globalizado.

Inauguran la parte icónica dos páginas manuscritas del diario del escritor, fechadas 4 de octubre de 1987, donde se alude a un verso del poema (Abad Faciolince, "Un poema en el bolsillo" 18-19). La segunda imagen reproduce la página del Magazín Dominical de El Espectador donde el 29 de noviembre el escritor había publicado "Apuntes para una biografía". El artículo se refiere al padre, cuya foto sonriente, al lado de un 
bebé, ocupa la portada del suplemento, reproducida en pequeño formato en el ángulo inferior izquierdo de la página par. El tamaño de la imagen tiene su incidencia semiótica, aquí neutraliza pudorosamente el punctum del retrato fotográfico que perturba y hiere (Barthes 59), pues se cruzan las miradas de la víctima futura y del lector/espectador testigo. La tercera ilustración muestra la última página de "Apuntes para una biografía". Sigue, al lado, "Filosofía de la Salud Pública", un texto del propio Héctor Abad Gómez, otro vínculo a la vista. El hijo termina su escrito con el poema, un recorte ampliado que tapa la parte de la página de donde está sacado. Con esta mise en abyme tipográfica el autor realza la imagen del detalle fundacional (Abad Faciolince, "Un poema en el bolsillo" 22-25). Finalmente, el poema reaparece tallado en la lápida del cementerio, la cuarta imagen, precedida por un par de páginas explicativas donde sobresale un breve apóstrofe: "Aquí pueden todavía ver, o al menos adivinar, el poema, porque incluso las palabras cinceladas en piedra se van borrando, igual que la vida y tal como los sueños" (Abad Faciolince, "Un poema en el bolsillo" 26). A continuación, se propagan las singularidades visuales que articulan los enlaces entre la gente que el poema ha convocado, reunida al final en un diagrama. Es la abstracción visible de todos los tiempos — de todas las vivencias - que esta versión de "Un poema en el bolsillo" ha ido evocando. Completa el diagrama un mapa que deja constancia de todos los espacios — de todos los hábitats - que este montaje verbo-visual ha ido nombrando y mostrando. Son modelos convencionales y simplificados de una experiencia que no cabe en un único medium, que necesita la desarticulación y el remontaje del testimonio intermedial para inscribir también los restos silenciados del duelo, el pathos latente que tal vez encuentre nuevas salidas.

\section{Coda}

Antes de presentar en Madrid, el 3 de octubre de 2017, la reedición de Olvido que seremos y asistir a la proyección del documental Carta a una sombra, Héctor Abad Faciolince concede una entrevista, donde se le recuerda que un año antes había declarado que ya no se sentía víctima. Al preguntarle la periodista cómo y cuándo esto puede suceder, el escritor contesta:

Cuando lo cuentas. Ponerlo en un papel es muy útil. En el mundo contemporáneo basta la representación de la verdad para tener una especie de justicia simbólica, y la verdad es también la posibilidad del perdón. Y eso es lo que pasa ahora también en el conflicto colombiano. Los paramilitares fueron los que mataron a mi padre y cuando Uribe hizo la paz con ellos pensé: "Si esta gente cuenta la verdad a mí me importa un pepino la justicia, que tengan la oportunidad de morirse de viejos, la oportunidad que no le dieron a mi padre". No es que yo esté feliz, no es que los vaya a besar en un acto de perdón público... Pero hay otras víctimas que dicen que no, que tiene que haber un castigo. No podemos olvidar. (Marín Yarza)

El perdón, que se despliega "cuando el agravio permanece inexpiado y la culpa irreparada, y mientras la víctima no ha sido indemnizada de su daño" (Jankélévitch 18), no implica el olvido. Cuando atañe a un trauma, la memoria está siempre en movimiento, no hay certeza de que ningún testimonio sea definitivo y apaciguador. En la prensa 
nacional e internacional Héctor Abad Faciolince no para de tomar posición contra la violencia, mientras su obra publicada sigue atendiendo al cometido fructuoso. Mientras haya en el mundo ojos que le presten atención.

\section{Bibliografía}

Abad, Daniela y Miguel Salazar. Carta a una sombra. Producciones La Esperanza, Caracol Televisión, 2015.

Abad Faciolince, Héctor. "Un poema en el bolsillo". Letras Libres 95 (2009): 10-19. [Edición española]

Abad Faciolince, Héctor. "Un poema en el bolsillo". Traiciones de la memoria. Bogotá: Alfaguara, 2009. 11-185.

Abad, Héctor. "A las dos orillas" (13 julio 2013). Web. 30 diciembre 2020. [Versión original del artículo publicado en alemán "An beiden Ufern der Welt". Lettre International 100 (2013). Web. 30 diciembre 2020.]

Abad Faciolince, Héctor. "Un poeta, un filósofo, un tendero y un tropero". El Espectador (27 agosto 2016). Web. 30 diciembre 2020.

Abad Faciolince, Héctor. "Ya no me siento víctima". Babelia, El País (3 septiembre 2016). Web. 30 diciembre 2020.

Abad Faciolince, Héctor. "Explicar el fracaso". El País (4 octubre 2016). Web. 30 diciembre 2020.

Abad Faciolince, Héctor. El olvido que seremos. Madrid: Alfaguara, 2017.

Assman, Aleida e Ines Detmers (Ed.). Empathy and its Limits. Houndmills, Basingstoke: Palgrave Macmillan, 2016.

Barthes, Roland. La cámara lúcida. Nota sobre la fotografía. Barcelona: Paidós Ibérica, 1980.

Belting, Hans. "Imagen, medium, cuerpo: un nuevo acercamiento a la iconología". CIC Cuadernos de Información y Comunicación 20 (2015): 153-170.

Benveniste, Émile. Problemas de lingüistica general. México: Siglo XXI Editores, 1997.

Calabrese, Omar. "Detalle y fragmento". La era neobarroca. Madrid: Cátedra, 1999. 84 105.

Caruth, Cathy. Unclaimed Experience. Trauma, Narrative, and History. Baltimore/London: Johns Hopkins University Press, 1996.

Cavarero, Adriana. A più voci. Filosofia dell'espressione vocale. Milano: Feltrinelli, 2005.

Didi-Huberman, Georges. La imagen superviviente. Historia del arte y tiempo de los fantasmas según Aby Warburg. Madrid: Abada Editores, 2009.

Didi-Huberman, Georges. Lo que vemos, lo que nos mira. Buenos Aires: Manantial, 2014.

Didi-Huberman, Georges. Falenas. Ensayos sobre la aparición 2. Santander: Asociación Shangrila Textos Aparte, 2015.

Didi-Huberman, Georges. "Cuando las imágenes tocan lo real". Cuando las imágenes toman posición. Georges Didi-Huberman, Clément Chéroux y Javier Arnaldo. Madrid: Círculo de Bellas Artes, 2018. 7-36.

Erll, Astrid. "Travelling Memory”. Parallax 17.4 (2011): 4-18.

Escobar Mesa, Augusto. "Lectura sociocrítica de El olvido que seremos: de la culpa moral a la culpa ética"/"Sociocritical Reading of El olvido que seremos: from Moral Guilt 
to Ethical Guilt". Estudios de Literatura Colombiana 29 (julio-diciembre 2011): 165195. Web. 30 diciembre 2020.

Fassin, Didier y Richard Rechtman. L'empire du traumatisme. Enquête sur la condition de victime. Paris: Flammarion, 2011.

Ferraris, Maurizio. "La revolución documedial". Revista de Occidente 434-435 (julioagosto 2017): 9-47.

Ginzburg, Carlo, "Spie. Radici di un paradigma indiziario". Miti, emblemi, spie. Morfologia e storia. Torino: Einaudi, 1986. 158-193.

Halbwachs, Maurice. La memoria colectiva. Zaragoza: Prensas Universitarias de Zaragoza, 2004.

Hartog, François. "El tiempo de las víctimas". Revista de Estudios Sociales 44 (diciembre 2012): 12-19.

Hirsch, Marianne. “The Generation of Postmemory”. Poetics Today 29.1 (Spring 2008): 103-128.

Jakobson, Roman et al. Teoría de la literatura de los formalistas rusos. Ed. Tzvetan Todorov. Buenos Aires: Signos, 1978.

Jankélévitc, Vladimir. Elperdón. Barcelona: Seix Barral, 1999.

LaCapra, Dominick. Escribir la bistoria, escribir el trauma. Buenos Aires: Nueva Visión, 2005.

Lafuente, Javier. "El dolor de los Abad, el dolor de Colombia". Babelia, El País (28 agosto 2015). Web. 30 diciembre 2020.

López Pacheco, Jairo Antonio. "Accountability social, organizaciones no gubernamentales de derechos humanos y conflicto político en Colombia, 2002-2010". Revista Mexicana de Sociología 75.2 (abril-junio 2013): 255-286.

Luckhurst, Roger. The Trauma Question. London/New York: Routledge, 2008.

Marín Yarza, Maribel. "Héctor Abad Faciolince: 'Prefiero el perdón a la justicia”". El País (3 octubre 2017). Web. 30 diciembre 2020.

Mitchell, W.J.T. ¿Qué quieren las imágenes? Una critica de la cultura visual. Vitoria-Gasteiz/Buenos Aires: Sans Soleil Ediciones, 2017.

Moreno Millán, Franklin. "El concepto de paz en la Constitución Política de Colombia de 1991: reconstrucción dialéctica de su significado a partir de la jurisprudencia de la Corte Constitucional". Revista de Derecho Universidad Católica del Norte 21.2 (2014): 305-346.

Ricœur, Paul. La memoria, la historia, el olvido. Madrid: Editorial Trotta, 2003.

Rothberg, Michael. Multidirectional Memory. Remembering the Holocaust in the Age of Decolonization. Stanford: Stanford University Press, 2009.

Valencia Agudelo, Germán Darío y Carlos Alberto Mejía Walker. "Ley de Justicia y Paz, un balance de su primer lustro". Perfil de Coyuntura Económica 15 (agosto 2010): 59-77.

Valencia Villa, Hernando. "Introducción a la justicia transicional". Claves de la razón práctica 180 (marzo 2008): 76-82.

Violi, Patrizia. Paesaggi della memoria. Il trauma, lo spario, la storia. Milano: Bompiani, 2014.

White, Hayden. "Teoría literaria y escrito histórico". El texto histórico como artefacto literario y otros escritos. Barcelona/Buenos Aires/México: Ediciones Paidós I.C.E. de la Universidad Autónoma de Barcelona, 2003. 141-188. 